\title{
距離動画像を用いた頭部ジェスチャの認識
}

\author{
梅 田和 昇*1 鈴 木 範 史 $^{* 2}$

\section{Recognition of Head Gestures Using a Sequence of Range Images}

Kazunori Umeda*1 and Norihito Suzuki*2

\begin{abstract}
Gesture recognition using images is recently studied as a technology of human friendly man-machine interface. In this paper, recognition of 3D gesture by using range images is discussed. Two methods for recognizing head gestures from a sequence of range images are proposed. One uses differential range images for identifying 'Yes' motion, and the other detects and tracks nose position for identifying 'Yes' and 'No' motion. Experiments to recognize real person's gestures using a range sensor system are performed to show the effectiveness of the presented methods.
\end{abstract}

Key Words: Gesture Recognition, Range Image, Motion Recognition, Man-Machine Interface

1. 序

論

今日，マンマシンインタフェース技術の重要性が高まってき ている。これらの技術においては，人間に対する自然さが重要 な要素の一つである. 人間は言語, 表情, ジェスチャなどのチャ ンネルを用いてコミュニケーションを行っており，これらを用 いたインタフェース技術を構築すれば，人間に対して自然なも のになると期待される [1]. 自然なインタフェースを目指した技 術の一つとして，ジェスチャの認識により人間から機械へ情報 伝達する手法が近年多く研究されている [2] [3]. これらの研究 ではジェスチャを観測するためのセンサ情報として，濃淡画像 が用いられている。しかしながら, 濃淡画像は三次元の位置情 報が二次元に射影された情報しか持たない。そこで，三次元の ジェスチャを認識するために，三次元情報を直接持つ距離画像 の利用が有効であると考えられる. かつては距離画像は入力に 時間を要し, 実時間性を要する目的には適さなかった。しかし ながら最近, 距離画像を実時間で入力可能なセンサが種々開発 されてきており [4] [8], 距離画像が実時間性を要する目的に 利用できるようになってきた。 ジェスチャ認識のためのセンサ 情報として, 距離画像は以下の 2 点の長所を持つと考えられる.

•三次元情報を持つため, 三次元的なジェスチャの認識に適 している

原稿受付 1998 年 5 月 8 日

*1 中央大学理工学部

$* 2$ 中央大学大学院理工学研究科 (現 NTT)

${ }^{* 1}$ Faculty of Science and Engineering, Chuo University

${ }^{* 2}$ Graduate School of Science and Engineering, Chuo University
・背景と対象領域との間に距離の不連続性が存在するため, 背景からの対象領域（人物）の抽出が容易かつロバストトで ある

以上より，本論文では，距離画像を用いたジェスチャ認識手 法を提案することを目的とする，具体的な認識対象として，頭 部のジェスチャを取り上げ, 特にうなずき動作, 首振り動作を 対象として，それらの識別手法を構築する。まず距離画像を用 いたジェスチャ認識手法の概要を示した後, 頭部のジェスチャ の具体的な認識手法を 2 種提案し, 実験でこれらの手法の有効 性,ひいては距離画像を用いたジェスチャ認識の有効性を検証 する.

\section{2. 距離画像を用いたジェスチャ認識手法の概要}

何らかの認識手法の構築を考える場合, 汎用的な手法を構筑 する場合と, 特定の認識対象に固有の手法を構築する場合とが 考えられる。これまでの濃淡画像を用いたジェスチャ認識の研 究では, 汎用的な手法の構築を目指したものが多い [2] [3]（例 えば [2]では HMM を, [3]では連続 DP を利用). 本論文では, うなずき動作，首振り動作の認識のみに特化した手法を構築す るという立場をとる。

画像の時系列からのジェスチャ認識は, 大きく, 特徽抽出, 抽出された特徽の時系列を用いた認識, の 2 段階の過程で行わ れると考えられる. 抽出される特徴に着目すると, ジェスチャ 認識手法は次の 2 通りに分類されると考えられる.

（1）各画像から静的な特徵を抽出する手法

（2）連続する画像から動的な特徵を抽出する手法

両方法論のいずれが適しているかは, 認識対象, 計算コスト などに依存すると考えられる，以下, 頭部のジェスチャ認識に 
おいて，両者を検討する。

（1）に属する手法：これまでの濃淡画像を用いた手法はこち らに属しているものが多い [2] [3]. 距離画像を用いる場合，各 画像で顔の認識を行って位置・姿勢を計測し，位置・姿勢を特 徵として用いるという方法がまず考えられる．顔は曲面であ り，これまでに提案されている距離画像を用いた曲面形状の認 識手法が適用しうると考えられる [9] [10].これらの研究では， 形状を，局所的な曲率やエッジ情報を用いて領域分割し，その 結果に基づいてモデルマッチングを行って位置・姿勢の計測を 行っている.このように各画像で顔の認識を行う場合, 安定に 顔の位置・姿勢の追跡が実現できると予想される反面，計算時 間を要するため, 実時間でのジェスチヤ認識を行うのは困難で ある。そこで本論文では，距離画像中の最も近い点を鼻とみな してその追跡を行うという，単純な手法を提案し，検証するこ ととする。

（2）に属する手法: 距離画像から得られる動的な特徴として, 顔はほぼ剛体であると仮定できるので，まず剛体の三次元運動 パラメータ [11][12]䒹えられる。この三次元運動パラメータ の時系列を利用すれば，汎用的な運動パターン認識が可能であ ると予想される。しかしながら，顔の形状が比較的平面に近い ため, 三次元運動パラメー夕の 6 成分すべてをロバストに求め るのは困難である [12]．そこで，本論文では，うなずき，首振 り動作さえ認識できればよいという立場から，簡単に計測可能 な差分距離画像を利用して，距離画像の誤差にロバストな認識 手法を構築することとする。

以上をまとめ, 本論文では, 頭部のジェスチャの認識手法と して，上記のそれぞれのカテゴリに属する手法として，差分距 離画像を動的な特徴として利用する（2）に属する手法を 3 で 提案し, 鼻の各画像での位置を特徵として利用する（1）に属 する手法を 4 で提案することとする。

\section{3. 差分距離画像を利用したうなずき動作の識別}

\section{1 手法構築の指針}

頭部の動きによるジェスチャとして，

・うなずき動作 ('Yes' motion)

- 首振り動作 ('No' motion)

・首をかしげる動作 ('Question' motion)

などが考えられる．本節ではうなずき動作を他の動作から識別 する手法を提案する．頭部のジェスチャでは，位置の変動が頭 部の大きさと比較して相対的に小さく，2枚の連続する画像で 重なりが大きいと考えられる。 そこで，差分距離画像が有効に 利用できると考えられる．差分距離画像は， 2 枚の連続する距 離画像の距離值の差を要素とする画像として定義される．以下 では，2枚の画像が重なっている領域のみを処理対象とする。 画像が重ならない領域では，距離值の差が重なる領域より大き くなると考えられる。そこで, 画像が重なっている領域のみで の差分距離画像は, 距離值の差が適当なしきい值より大きな筒 所を除くことで求められる。このようにして求められる差分距 離画像の各要素の差分值を $d_{i}$, 座標值を $\left(u_{i}, v_{i}\right)(i=1 \ldots N)$ とおく. $N$ は差分距離画像の要素数である.

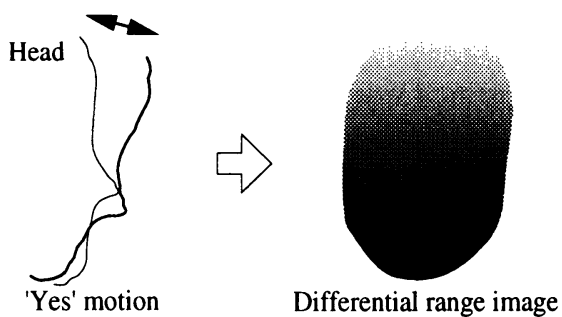

(a) 'Yes' motion

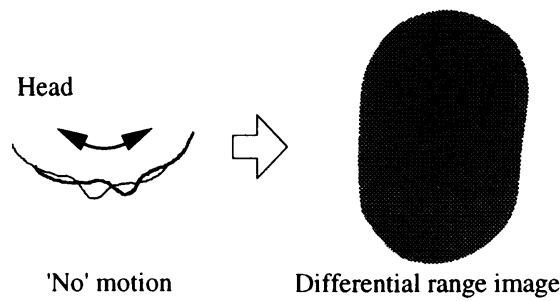

(b) 'No' motion

Fig. 1 Differential range image in 'Yes'/'No' motions (Intensity represents differential value)

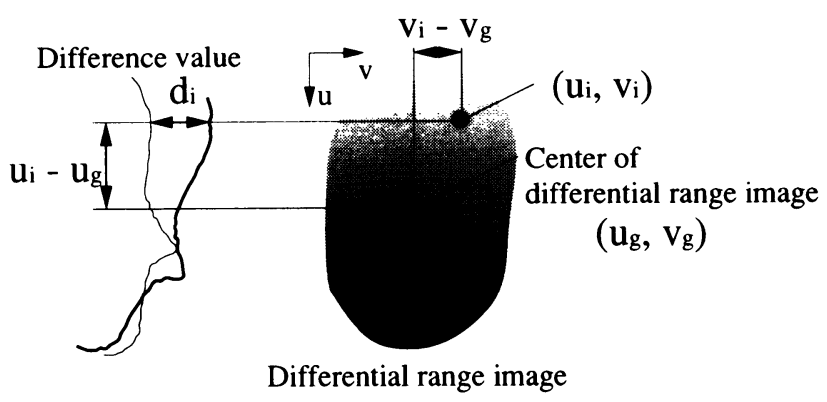

Fig. 2 Differential range image in 'Yes' motion

差分距離面像中の差分值は，うなずき動作において，縦方向 には連続的に大きく変化し，横方向には変化しないと考えられ る（Fig. 1 (a) 参照）。この性質を利用して識別手法を提案す る。なお，首振り動作においては，回転中心が頭部の回転中心 を通っており，差分距離画像の横方向に差分值はそれほど変化 しない (Fig. 1 (b) 参照).

\section{2 識別手法の提案}

上記の指針より，以下の式（1）(2）をうなずき動作の識別の ための基本式としてまず提案する。

$$
\begin{aligned}
& I_{v}=\frac{1}{N} \sum_{i=1}^{N}\left(u_{i}-u_{g}\right) d_{i} \\
& I_{h}=\frac{1}{N} \sum_{i=1}^{N}\left(v_{i}-v_{g}\right) d_{i}
\end{aligned}
$$

ただし， $\left(u_{g}, v_{g}\right)$ は差分距離画像の中心，すなわち，

$$
u_{g}=\frac{1}{N} \sum_{i=1}^{N} u_{i}, \quad v_{g}=\frac{1}{N} \sum_{i=1}^{N} v_{i}
$$

とする.これらのパラメータを Fig. 2 に示す. 
式（1）(2）は，それぞれ差分距離画像の中心からの縦方向, 横方向の変位で重みづけされた差分值の, 差分距離画像全体で の平均值である，うなずき動作では，式（1）が大，式 (2) が 小になると考えられる。なお，式（1）(2) は頭部の並進運動に よっては值を生じない。

式 (1)（2）の值は, 動作の反復に応じて振動する．振動成分 を抽出するのにはいくつか手法が考えられるが，ここでは単純 に，連続する適当枚数の差分距離画像で式 (1)(2) の絶対值を 積算し平均する。 そしてこれらの值を，識別のための評価值と して用いることとする。すなわち，評価值として，

$$
\begin{aligned}
& J_{v}(t)=\sum_{i=t-n+1}^{t} \frac{\left|I_{v}(i)\right|}{n} \\
& J_{h}(t)=\sum_{i=t-n+1}^{t} \frac{\left|I_{h}(i)\right|}{n}
\end{aligned}
$$

を用いる。ここで， $n$ は積算する差分距離画像の枚数である. あるいは, 式 $(4)$ の $J_{h}(t)$ を, 式 $(3)$ の $J_{v}(t)$ で規格化して (すなわち $\left.\left.J_{h}(t) / J_{v}(t)\right)\right)$ 用いることも可能である.これらの 評価值を用いれば，以下の基準でうなずき動作を識別できる。

$$
\text { if }\left(J_{v} \text { 大 and } J_{h} \text { 小 }\right) \text { then うなずき動作 }
$$

この識別は, $n$ 枚の差分距離画像（すなわち $(n+1)$ 枚の距 離画像）が計測されて以後は各時刻 $t$ において行われる。 また, 実際に認識システムを構築する場合には複数の時刻での識別結 果を組み合わせることも考えられる。

以上，差分距離画像を用いたうなずき動作の識別手法を提案 した.

\section{3 差分距離画像の積算枚数などに関する考察}

以上で提案した手法における, 差分距離画像の積算枚数 $n$ な どに関して考察する.式 $(1)(2)$ の $I_{v}, I_{h}$ は, Fig. 3 に模式 的に示すように，うなずき動作の反復に応じて正弦波的に振動 すると考えられる。.また，式（3)(4) の $J_{v} ， J_{h}$ は，それぞれ $I_{v}, I_{h}$ のある区間の面積を積分して求めた量（を積算枚数 $n$ で割った量）に相当する。このとき，積分する区間が短いと， 振動する $I_{v}, I_{h}$ のどの位相で計測するかにより， $J_{v}, J_{h}$ が変 動してしまうことになる．積分区間の取り方による值の変動を 最小值と最大值との比 $r$ で求めると, $x$ を積分区間の幅（正弦 波の周期で規格化)， $[x]$ を $x$ を越えない最大の整数として,

$$
r= \begin{cases}\frac{2[x]+1-\cos \pi(x-[x])}{2[x]+\sin \pi(x-[x])} & \left(x-[x]<\frac{1}{2}\right) \\ \frac{2[x]+2-\sin \pi(x-[x])}{2[x]+1-\cos \pi(x-[x])} & \left(\frac{1}{2} \leq x-[x]\right)\end{cases}
$$

となる.これを図示すると Fig. 4 のようになる.

Fig. 4 より, 計測のタイミングによる $J_{v}, J_{h}$ の值の変動が 大きくならないようにするには，最低でも積算時間をうなずき 動作の周期の $1 / 2$ 以上, 可能ならば 1 周期分以上にすることが 望ましいことが分かる（また，実際の応用を考えた場合，うな ずき動作の周期は一定ではなく変動する。変動分を考慮して， 積算時間には余裕を持たすことが必要である)。また，積算時 間が長くなることは，うなずき以外の動作を分離する点からも

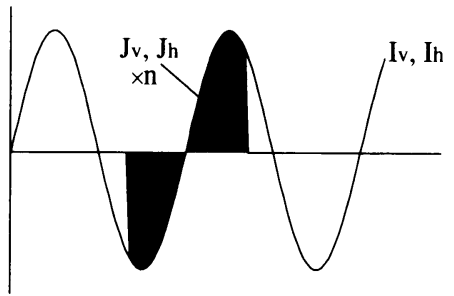

Fig. 3 Relation of $I_{v}, I_{h}$ and $J_{v}, J_{h}$

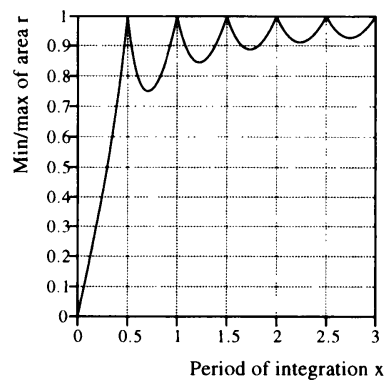

Fig. $4 \mathrm{Min} / \max$ of area according to period of integration

望ましいと考えられる。ただし，時間が長くなりすぎると，識 別を行うのに要する時間がそれに応じて長くなってしまう.

積算時間は, 差分距離画像の積算枚数 $n$ と距離動画像計測の サンプリングタイムとの積で与えられる。サンプリングタイム は，一般的に計測システムの能力で上限が設定される。 サンプ リング定理より，最低でもうなずき動作 1 周期あたり 2 回以上 の計測が必要であると考えられる。サンプリングタイムはなる べく短い方が良いと考えられるが，短すぎると差分距離画像の 差分值が小さくなってしまう.

以上, 差分距離画像の積算枚数 $n$ (とサンプリングタイムと の積で与えられる積算時間）とサンプリングタイムに関しての 定性的な考察を行った。

\section{4.鼻の抽出・追跡によるうなずき・首振り動作の識別}

前章で差分距離画像という動的な特徴を利用した識別手法を 提案したのに対し，本節では静的な特徵を利用した手法を提案 する．静的な特徴として鼻の位置を用いる。これは，

・鼻が顔の中心にあり, 顔を代表する特徵として適切である と考えられる

・距離画像からの抽出が容易であると考えられる という理由による。

(1) 鼻の位置の抽出・追跡

鼻は, 顔のほぼ中心にあり, 周辺で距離が最も近い領域であ ると仮定できる。 そこで, 以下の手順で時系列距離画像からの 鼻の位置の抽出・追跡を行う.

1 枚目の画像：顔の距離画像の中心付近で最も距離が近い点 を探索し，鼻とみなす。

2 枚目以降の画像：前の画像の鼻の抽出位置の近傍で距離が 最も近い点を探索し，鼻とみなす.

同様の追跡は, 近年よく用いられているトラッキングビジョ ンなどを利用することによって, 濃淡画像でも可能であると考 
えられる [13]. 本手法と, トラッキングビジョンなどにおいて 用いられている相関演算による追跡とを比較すると, 濃淡画像 の利用よりも本手法のように距離值を利用する方が, 照明など の環境の変化に対してはロバストであると考えられる.ただし， 本手法では, 距離画像中の 1 点のみの抽出を行うため, 距離画 像の距離值の, 通常の正規分布に従わない大きなノイズには弱 い。これは利用する距離画像センサの特性にも依存し, 使用す るセンサの誤差が正規分布によく従うならば，問題にはならな い.この問題に本質的に対処するには，2で述べたような位置・ 姿勢の計測を行うか, あるいは距離画像においても近傍領域で の相関演算を行えばよいと考えられる.

(2) 鼻の位置の時系列からのうなずき・首振り動作の識別 距離画像の時系列から得られる鼻の位置の時系列より, うな ずき動作・首振り動作を識別する，うなずき動作では，鼻の位 置は画像中で上下に, 首振り動作では左右に振動する（Fig. 5 参照). 鼻の位置の振動成分を求めるにもいくつか手法が考え られるが，ここでは 3 と同様の単純な手法を用いる。すすおち，

$$
\begin{aligned}
& a_{v}(t)=\sum_{i=t-n+1}^{t} \frac{\left|u_{\text {nose }}(i)-u_{\text {nose_ave }}(t)\right|}{n} \\
& a_{h}(t)=\sum_{i=t-n+1}^{t} \frac{\left|v_{\text {nose }}(i)-v_{\text {nose_ave }}(t)\right|}{n}
\end{aligned}
$$

により縦方向の振動成分 $a_{v}$, 横方向の振動成分 $a_{h}$ を計測す る. ただし, $n$ は積算する距離画像の枚数, $u_{\text {nose }}(i), v_{n o s e}(i)$ は画像 $i$ での鼻の縦・横の位置, $u_{\text {nose_ave }}(t), v_{\text {nose_ave }}(t)$ は 画像 $t$ から $n$ 枚前までの画像での鼻の縦・横の位置の平均, す なわち

$$
\begin{aligned}
& u_{\text {nose_ave }}(t)=\frac{1}{n} \sum_{i=t-n+1}^{t} u_{n o s e}(i), \\
& v_{n o s e \_a v e}(t)=\frac{1}{n} \sum_{i=t-n+1}^{t} v_{n o s e}(i)
\end{aligned}
$$

である.

こうして求められた $a_{v}, a_{h}$ を用いて, 以下のように識別す ればよい。

if $\left(a_{v}\right.$ 大 and $a_{h}$ 小) then うなずき動作

if $\left(a_{v}\right.$ 小 and $a_{h}$ 大 $)$ then 首振り動作

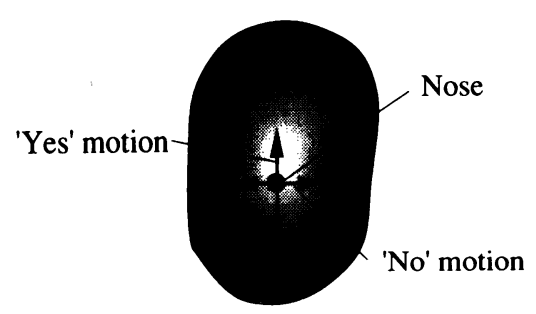

Range image of face

Fig. 5 Vibration of nose in 'Yes'/'No' motion (Intensity represents distance value)
この識別は, 3.2 節と同様に $n$ 枚の距離画像 $(3.2$ 節では差 分距離画像) が計測されて以後は各時刻 $t$ において行われる. また, 距離画像の積算枚数 $n$ およびサンプリングタイムに関し ては 3.3 節での議論がまったく同様に当てはまる.

以上，鼻の位置を用いたうなずき動作・首振り動作の識別手 法を提案した。

\section{5. 認 識 実 験}

提案した二つのジェスチヤ認識手法の有効性を検証するため の実験を行う. 5.1 節で実験システムの構成を示し， $5.2,5.3$ 節でそれぞれ差分距離画像を用いた手法, 鼻の追跡を用いた手 法の実験結果を示す. 5.4 節では, 3.3 節で考察した差分距離 画像の積算枚数およびサンプリングタイムが与える影響を評価 する実験を行う。また, 5.5 節では 2 手法の比較実験を行う。

\section{1 実験システムの構成}

実験システムの構成を Fig. 6 に示す. 距離画像センサ, パー ソナルコンピュータ（DX4100[MHz]）が主な構成要素であ る. 距離画像センサには文献 [5] で示されているものを改良し たセンサを用いた。本センサは, Fig. 6 に示すように, 多点の スポット光を投影し, 各スポット像までの 8 ビットの距離値を 三角測量によりビデオレートで計測する. 計測点数は 1,056 点 で, 測定レンジは約 $760[\mathrm{~mm}] \sim 850[\mathrm{~mm}]$ である. 8 ビットの 距離値は, 三角測量の視差に相当する量を表している [5]. 実際 の距離值への対応は，0のときが約 $760[\mathrm{~mm}], 255$ のときが約 $850[\mathrm{~mm}]$ となり, この間で 8 ビットの距離值と実際の距離值と はほほ線形に対応づけられる. 本実験では処理の高速化のため 実際の距離值への変換は行わず 8 ビットの距離值をそのまま用 いた.

Fig. 7 に示すように被験者にセンサの前に座ってもらい, 頭 部のジェスチャを観察した．本センサではハロゲンランプによ る可視光のスポット光を投影して距離を計測するため, 外乱光 に弱い，通常の室内程度の明るさでの計測は可能であるが, 以 下の実験は半暗室で行い (5.4 節は蛍光灯照明下), 外乱光の 影響を除去している.

なお，多点のスポット光の投影によるセンサを用いた本実験 システムは，あくまで提案手法の有効性を検証するための一例 であり，他の能動手法やステレオ, Shape from focusなどを用 いて得られた距離画像に対しても本論文の手法はまったく同様 に適用可能である.

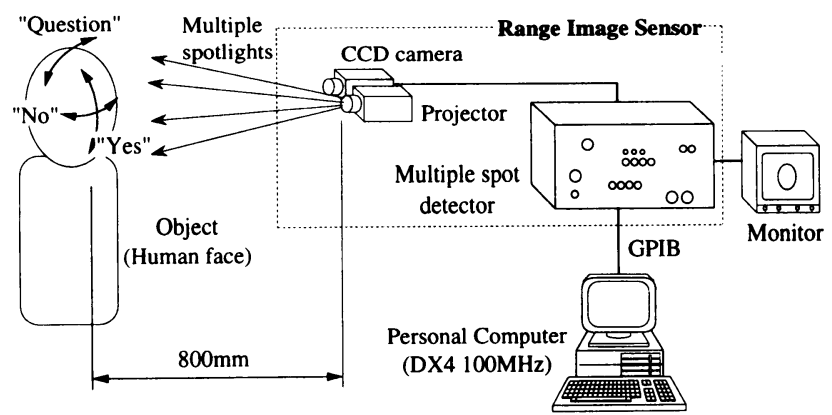

Fig. 6 Experimental system 


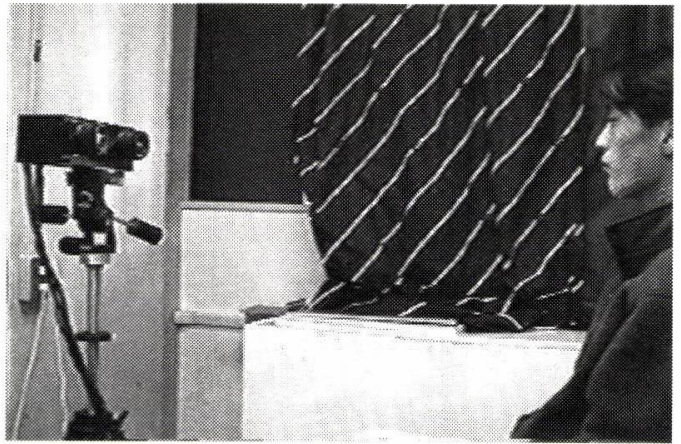

Fig. 7 Experimental environment - projector, CCD camera and an object person

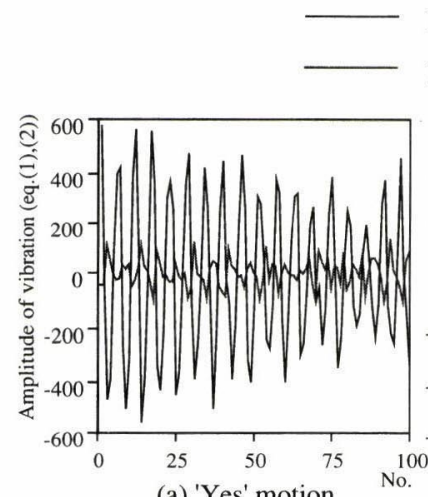

$I_{v}$ (vertical)

(a) 'Yes' motion

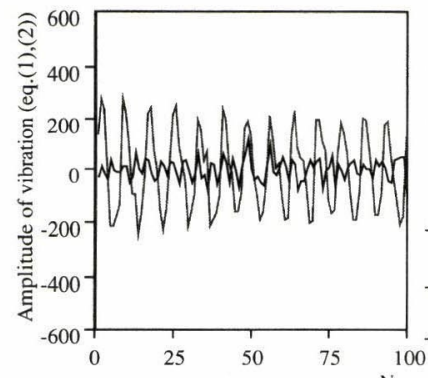

(c) 'Question' motion No.

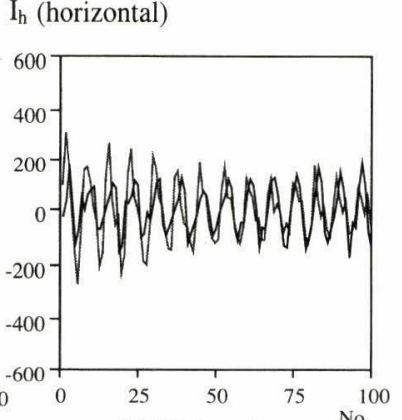

(b) 'No' motion

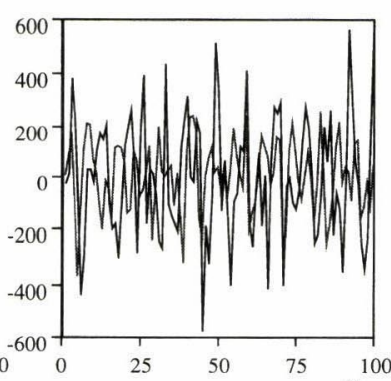

(d) Random motion No.

Fig. 8 Weighted averages of differential values for 'Yes', 'No', 'Question' and random motions

\section{2 差分距離画像を利用したうなずき動作の識別実験}

うなずき動作, 首振り動作, 首をかしげる動作, 頭部をラン ダムに動かす動作の 4 種の動作に対して，3の手法を適用した。 差分距離画像の積算枚数（式 $(3)(4)$ の $n$ ) はここでは適当に 10 とした．動作中の顔に対し，100枚の距離画像を時系列で入 カし, オンラインで処理を行った。 うなずき動作, 首振り動作, 首をかしげる動作で周期が $1.2 \sim 1.6$ 秒, サンプリングタイムは 0.3 秒以下であった。

Fig. 8 に差分距離画像における差分值の重みつき平均（式 (1) (2)) を示す。本図より，うなずき動作では縦方向の平均の 振幅が他の動作の場合より大きく，また横方向の平均の振幅は それほど他の動作と差はないが，相対的に小さいことが示され ている。

縦・横それぞれの評価関数（式 $(3)(4))$ を Fig.9 に示す.

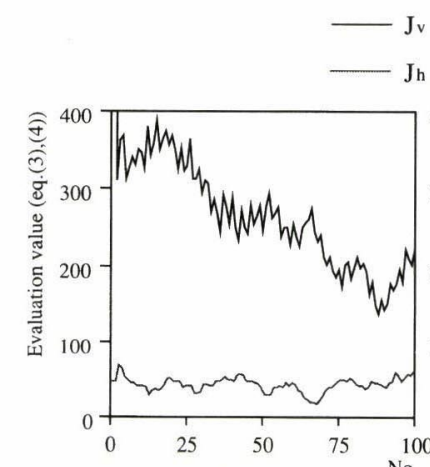

(a) 'Yes' motion

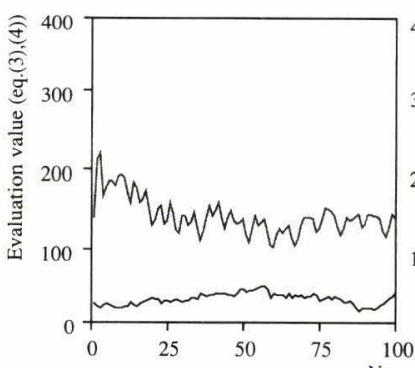

(c) 'Question' motion
$\mathrm{J}_{\mathrm{v}}$ (vertical)

h (horizontal)

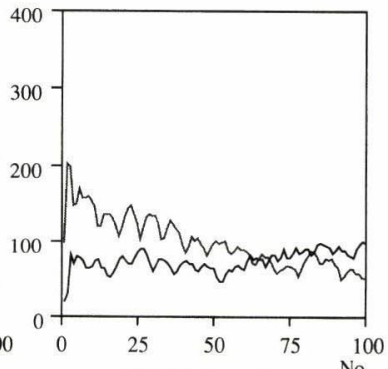

(b) 'No' motion

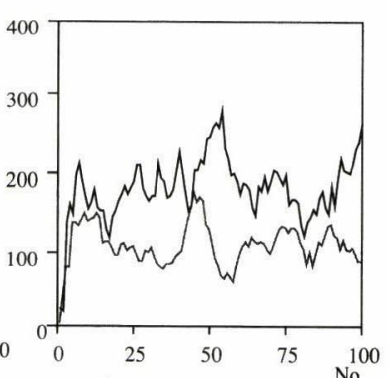

(d) Random motion
Fig. 9 Evaluation functions for 'Yes', 'No', 'Question' and random motions

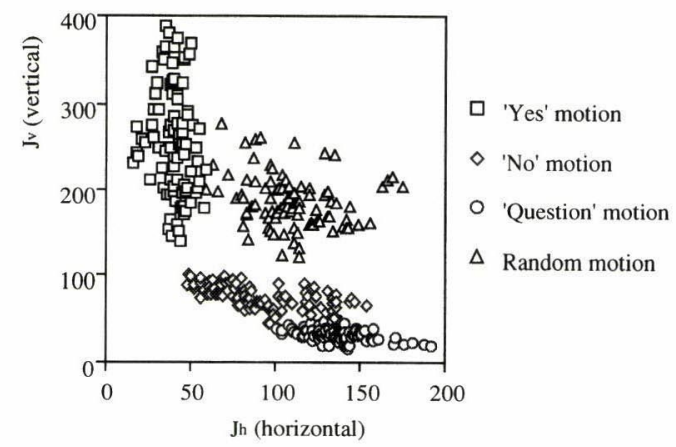

Fig. 10 Distribution of vertical-horizontal evaluation functions of differential range images

本図より，うなずき動作では縦方向の評価值が高い值で，また 横方向の評価值が低い值で推移している。ささら Fig. 10 に縦 方向, 横方向の評価值を縦軸・横軸にとった図を示す。ランダ ムな動作での值が一部接近しているものの，ほぼうなずき動作 を分離可能である.

以上の結果より，3 章で示した判断基準でうなずき動作が他 の動作より識別可能であることが示されている。一方，うなず き動作以外の識別は, これらの值からでは困難である。

5.3 鼻の抽出・追跡によるうなずき・首振り動作の識別実験

うなずき動作, 首振り動作の 2 種の動作に対して, 4 の手法 を適用した。距離画像の積算枚数 (式 $(6)(7)$ の $n$ ) は前項の 実験と同じく適当に 10 とした. 動作中の顔に対し, 30 枚の距 離画像を時系列で大力し, 鼻の抽出・追跡をオンラインで, 評 価值の算出のみをオフラインで行った。 


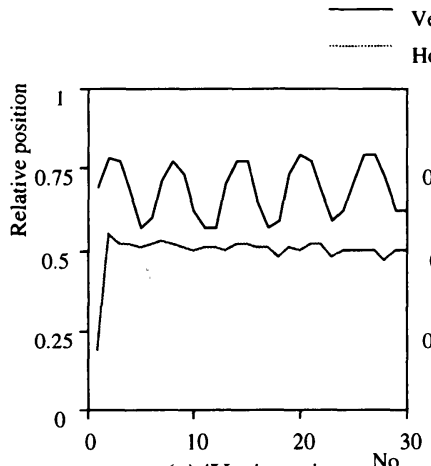

(a) 'Yes' motion
Vertical position

orizontal position

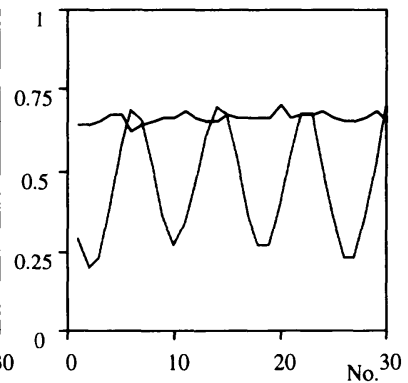

(b) 'No' motion
Fig. 11 Tracking of nose position for 'Yes' and 'No' motions

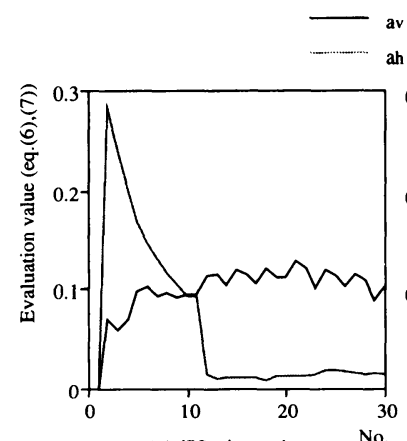

(a) 'Yes' motion

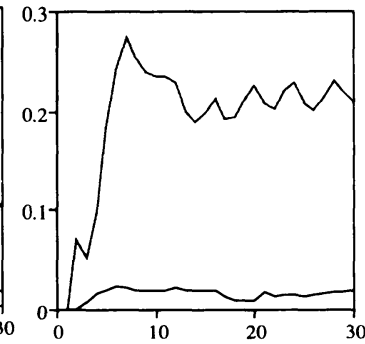

(b) 'No' motion No.
Fig. 12 Evaluation functions for 'Yes' and 'No' motions

Fig. 11 より，うなずき動作においては縦方向の振幅が大き く，また横方向の振幅が小さく計測され，一方首振り動作にお いては逆に横方向の振幅が大きく，また縦方向の振幅が小さく 計測されていることが分かる，さらに，Fig. 12 では，評価值 が，うなずき動作における初期の值以外，式（8)(9) に示す基 準に従っている.Fig. 13 に評価值の分布を示す. 本図での両 動作の空間的な分布は特徴的であり,これらの他の動作からの 分離は容易であると考えられる。

以上の結果より，4 章で示した判断基準でうなずき動作，首 振り動作が識別可能であることが示されている。また，うなず き動作と首振り動作とでは，うなずき動作の方が振幅が大きく でることも Fig. 11，12 に示されている.

5.4 積算枚数およびサンプリングタイムの影鳘の評価実験 差分距離画像を用いたうなずき動作の識別において, 積算枚 数およびサンプリングタイムが識別能力に与える影響を評価す る実験を行った。本実験では距離画像の入力のみをオンライン で行い, その後の識別処理に関してはすべてオフラインで行っ た．距離画像入力のサンプリングタイムはビデオレートの 5 倍 で $5 / 30$ 秒であった。なお，実験で用いた距離画像センサ自体 はビデオレートでの計測を行う能力があるが, GPIB イン夕 フェースなどでのオーバーヘッドでこれだけの時間を要してい る.また，オフラインで行った識別処理で 1 サンプリングの処 理に要する時間は $30[\mathrm{msec}]$ 以下と高速であった。

識別を行うためのしきい值は実験により適当に定めた。式 （5）において $J_{v}>50$ かつ $J_{h} / J_{v}<0.2$ を満たしたときにう

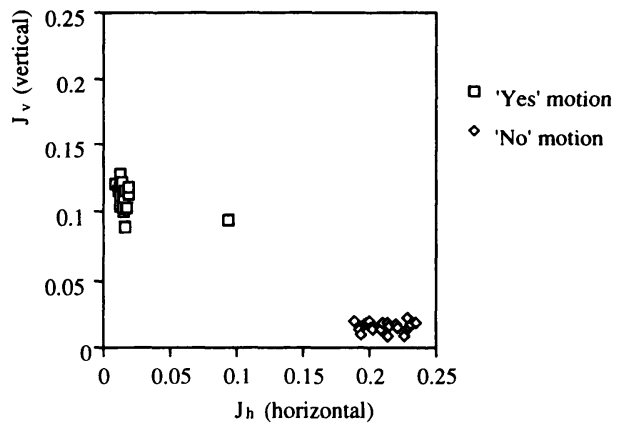

Fig. 13 Distribution of vertical-horizontal evaluation functions of nose tracking

なずき動作と識別した。ここでは，うなずき動作を正しくうな ずき動作であると識別する割合，およびうなずき動作以外をう なずき動作と誤って識別する割合を計測し, 識別能力を評価し た. Fig. 10 に示されているように，うなずき動作以外で最もう なずき動作と誤って識別しやすいのはランダム動作である。そ こで，うなずき動作以外としてランダム動作を対象とした。

(1) 差分距離画像の積算枚数の影響

差分距離画像の積算枚数（式 $(3)(4)$ の $n$ ) $1 \sim 20$ 枚に変 化させたときのうなずき動作の識別率を検証した。うなずき動 作，ランダム動作を行っている人の顔の距離画像を $5 / 30$ 秒間 隔で 200 枚あまり，計 5 回ずつ計測した。その結果，うなずき 動作，ランダム動作それぞれに対して合計 985 回の識別結果を 得た。また，うなずき動作の周期は 1.6〜1.8 秒で， 1 周期あた りの差分距離画像の計測数は約 10 枚であった.

うなずき動作を正しくうなずき動作と識別した割合およびラ ンダム動作をうなずき動作と䛊って識別した割合を Fig. 14 に 示す. Fig. 14 より, 差分距離画像の積算枚数が 10 あたりから （すなわち 1 周期分の積算時間あたりから）識別能力が高くな り, 積算枚数が増加するに従って識別能力が向上し続けること が示されている。しかしながら，むやみに枚数を増加させれば， それだけ入力時間が長くなってしまう。例えば $n=20$ では積 算時間は 3.3 秒以上であり，動作を行う人物は最低それだけの 時間, うなずき動作を続ける必要がある. 現実の問題では, 識 別能力と入力時間とのトレードオフを考える必要がある.

(2) サンプリングタイムの影響

サンプリングタイムを1〜10 倍に変化させたときのうなずき 動作の識別率を検証した. 差分距離画像の積算枚数 $n$ は 10 と した。上記と同じ距離動画像から $k$ 枚ごとに画像を選択するこ とで $k$ 倍のサンプリングタイムを擬似的に実現した。そののめ 識別結果を得た数はサンプリングタイムにより異なっており，1 倍から 10 倍まで順に, $1035,495,315,225,170,135,105,90,75,60$ 回であった。うなずき動作を正しくうなずき動作と識別した割 合およびランダム動作をうなずき動作と誤って識別した割合を Fig. 15 に示す. Fig. 15 を見る限りでは，8倍のサンプリング タイムまで高い識別能力を示している。しかしながら，サン プリングタイムが 5 倍以上では， 1 倍での一周期あたりの距離 画像の計測数が約 10 枚であるので一周期に 2 枚以下の計測と なってサンプリング定理を満たさなくなる. Fig. 16 に 1,3,5,6 


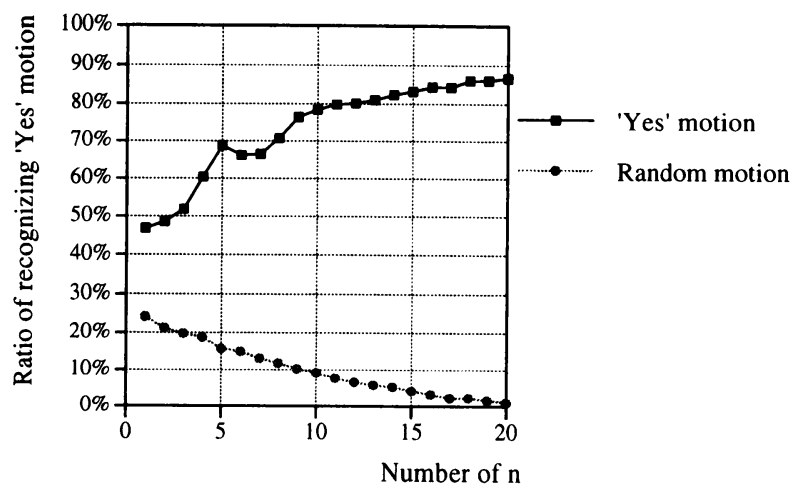

Fig. 14 Change of ratio of recognizing 'Yes' motion according to number of differential images

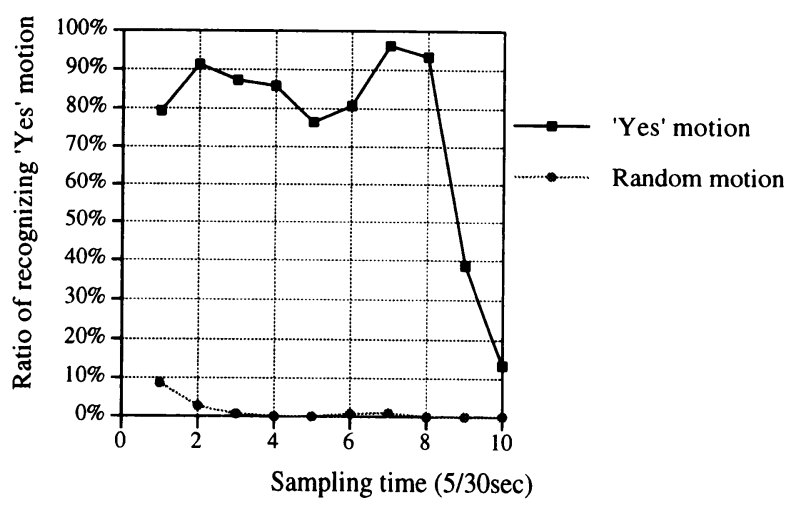

Fig. 15 Change of ratio of recognizing 'Yes' motion according to sampling time

倍のサンプリングタイムでの式 (1) の縦方向の重みつき平均 の值を示す. 四つの図で横方向の枚数はサンプリングタイムに 応じて調整してある. Fig. 16 より 1,3 倍で 22 個計測されてい るピークが, 5,6 倍ではすべては計測されていないことが分か る.この結果から, サンプリング定理を満たす範囲内でのサン プリングタイムを用いることが望ましいと考えられる。実際， Fig. 15 では 9,10 倍のサンプリングタイムで識別率が大きく落 ちている。これはサンプリングタイムがほぼうなずき動作の周 期と一致し，差分が小さくなってしまったためと考えられる。 また， 1 倍より 2 倍以上の方がランダム動作を䛊ってうなずき 動作と識別する割合が小さくなっているが，これは積算時間が 長くなり, ランダム動作中で部分的にうなずき的な動作が入っ てしまうのを誤ってうなずき動作と識別することが少なくなっ たためと思われる。

\section{5 両手法の識別率比較}

3,4 章で提案した両手法によるうなずき・首振り動作の識 別率の評価実験を行った。識別のためのしきい值は実験により 適当に定めた. 式 (5) において $J_{v}>80$ かつ $J_{h} / J_{v}<0.4$ を 満たしたときにうなずき動作と識別した。また，式（8）にお いて $a_{v}>0.4$ かつ $a_{h}<0.4$ を満たしたときにうなずき動作， 式（9）に抽て $a_{v}<0.4$ かつ $a_{h}>0.5$ を満たしたときに首 振り動作と識別した。五人の被験者に対し，うなずき動作，首 振り動作を行ってもらい，100 枚の距離画像を入力して識別し

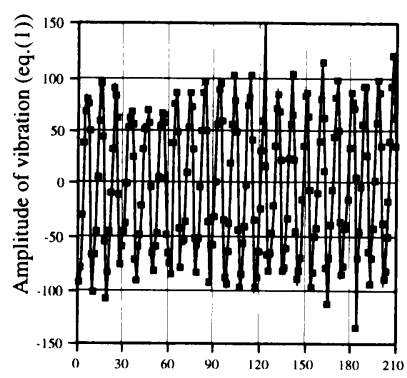

(a) $5 / 30 \times 1 \mathrm{sec}$

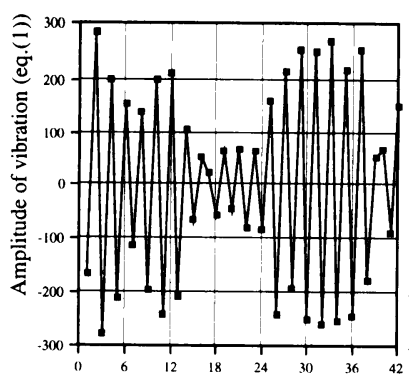

(c) $5 / 30 \times 5 \mathrm{sec}$ No

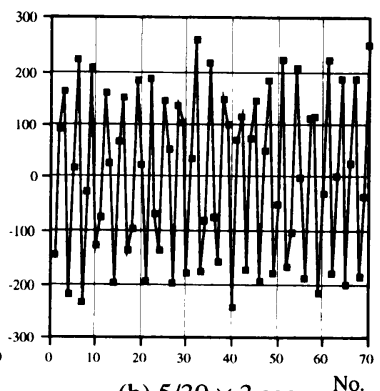

(b) $5 / 30 \times 3 \mathrm{sec}$

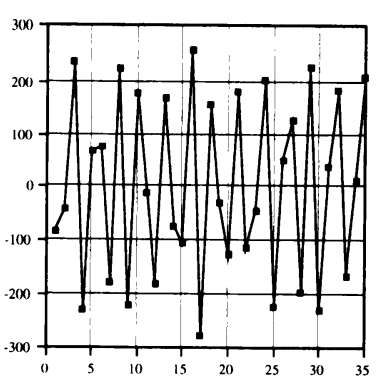

(d) $5 / 30 \times 6 \mathrm{sec} \quad$ No.
Fig. 16 Weighted averages of differential values in eq.(1) for several sampling times

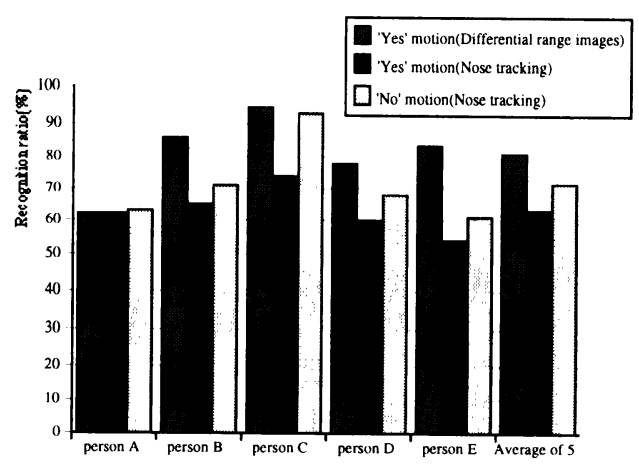

Fig. 17 Recognition rate of 'Yes' motion and 'No' motion

た結果をFig.17に示す．ここで示す識別率は, うなずき, 首 振りそれぞれの動作を正しく識別した割合である。

本図より，以下の結果が示されている。

・それぞれの手法で比較的高い識別率を実現している，なお， これらの実験での識別率は各サンプリング時においてのも のであるため，実際に認識システムを構築する場合には複 数の時刻での識別結果を組み合わせて実質的な識別率を向 上させることが可能である。

・うなずき動作の識別では，差分距離画像を用いた方が識別 率が高い。これは，4で示したように，本論文での鼻の抽 出が距離画像中の 1 点のみの抽出により行われているのに 対し, 差分距離画像による識別では, 多くの点での值を積 分するため，ノイズの影響が平均化されキャンセルされる ためと考えられる。例えば Fig. 11 (a) のうなずき動作にお ける横方向の振動の最初のデータが距離值の誤差の影響を 受けて不正確になっているのもこのためである. 
・鼻追跡手法では，鼻の振幅が大きい首振り動作の方が，う なずき動作より識別率が良い.

以上の結果（特に後の 2 項）を考慮すると, 本センサシステ ムを用いた頭部ジェスチャ認識システムとしては，うなずき動 作の識別を行うには差分距離画像を利用し, 鼻の抽出・追跡に よる識別は首振り動作の識別にのみ利用するのが妥当であると 考えられる。実際，このように 2 手法を組み合わせて同様に被 験者 5 名に対して 100 枚の距離画像を入力して実験を行ったと ころ，平均でうなずき動作 $77.6 \%$ ，首振り動作 $82.6 \%$ あ゙あっ 2 手法の併用による処理時間のオーバーヘッドがあるにもかか わらず，鼻追跡手法のみでうなずき動作・首振り動作の認識を 行う場合（Fig. 17 参照）に比べて高い識別率を得ることがで きた。

\section{6. 結論}

機械へより自然に情報を伝達するための方法として，距離画 像を用いたジェスチャ認識手法を取り上げ，頭部のジェスチャ の認識手法として, 以下の二つの手法を提案し, 距離画像七 ンサを用いた基礎的な実験により，これらの手法の有効性を示 した。

・差分距離画像を利用したうなずき動作の識別

・鼻の抽出・追跡によるうなずき・首振り動作の識別

これら二つは, 識別のための特徴として, 複数画像から抽出さ れる動的なものを用いたか，1枚の画像から得られる静的なも のを用いたか，で位置づけが異なるものである、

本論文は, ジェスチャ認識における距離画像の有効性の例示, ならびに具体的な認識手法の提案という二つの側面を持つもの であり，それらが実験結果により示されたといえよう。

今後は理論・実験の両面から, 識別におけるしきい値の決定, 手法の適用範囲・ロバスト性の検証などを行っていくことが課 題である。さらに，モデルベース認識により得られる位置·姿 勢, 三次元運動パラメータなど，他の特徴の時系列を用いた， 汎用性の高い認識手法の実現, ならびに本論文での手法との比 較を行うことも今後の重要な課題である。

また，本論文で対象としたうなずき・首振り動作は，4で簡
単に触れたように, 濃淡画像を用いて認識を行うことも可能で あると考えられる。距離画像を用いる場合と濃淡画像を用いる 場合との認識特性の比較を行うこと, さらには距離画像と濃淡 画像とを組み合わせてよりロバストな認識システムを構築する ことも今後の重要な課題である.

謝 辞 実験装置に関してご助力下さったパイオニア (株) の武藤守男氏, 実験などでサポートをしてくれた中央大学大学 院の田中信也氏に深謝致します。

\section{参 考 文 献}

[1] 黑川隆夫：ハンバーバルインタフェース。オーム社, 1994.

[2] J. Yamato, J. Ohya and K. Ishii: "Recognizing human action in time-sequential images using hidden markov model," Proc. CVPR'92, pp.379-385, 1992.

[3] 高橋勝彦, 関進, 小島浩, 岡隆一：“動画像による人物動作のリアル 夕イム・スポッティング認識”, MIRU'94,pp.215-222, 1994.

[4] M. Hebert and E. Krotkov: "3-D measurements from imaging laser radars: how good are they?," IEEE/RSJ Int. Workshop on Intelligent Robots and Systems '91, pp.359-364, 1991.

[5] K. Sorimachi: "Active range pattern sensor," J. Robotics \& Mechatronics, vol.1, pp.269-273, 1989.

[6] K. Sato, A. Yokoyama and S. Inokuchi: "Silicon range findera realtime range finding VLSI," Proc. Custom Integrated Circuits Conf., pp.339-342, 1994.

[7] T. Kanade, A. Gruss and L.R. Carley: "A VLSI sensor based rangefinding system," Robotics Research Fifth International Symposium, pp.49-56, 1990.

[8] T. Kanade, H. Kano, S. Kimura, A. Yoshida and K. Oda: "Development of a video-rate stereo machine," Proc. IEEE Int. Conf. on IROS'95, vol.3, pp.95-100, 1995.

[9] 脇迫仁，鎌田清一郎，河口英二： “距離画像処理による 3 次元物体検 出システム”, 信学論, vol.J77-D-II, no.7, pp.1282-1292, 1994.

[10] 藤田武洋, 佐藤宏介, 井口征士: “局所曲面形状解析に基づくビンピッ キングのためのビジョンシステム”, 信学論, vol.J73-D-II, no.1, pp.46-53, 1990

[11] 山本正信他：“距離動画像を用いた非剛体運動パラメー夕の直接的推 定法”, 情処学論, vol.32, no.9, pp.1129-1141, 1991.

[12] T. Arai and K. Umeda: "Measurement of 3D Motion Parameters from Range Images," IEEE/RSJ Int. Workshop on Intelligent Robots and Systems '91, pp.383-388, 1991.

[13] H. Inoue et al: "Robot vision system with a correlation chip for real-time tracking, optical flow and depth map generation," Proc. 1992. IEEE Int. Conf RA, pp.1621-1626, 1992.

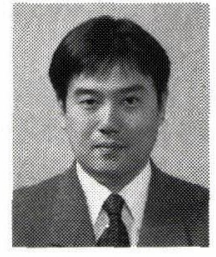

梅田和昇（Kazunori Umeda）

1967 年 2 月 6 日生. 1989 年東京大学工学部精密 機械工学科卒業. 1994 年同大学大学院精密機械工 学専攻博士課程修了. 博士 (工学). 同年中央大学 理工学部精密機械工学科専任講師, 1998 年より同 助教授、ロボットビジョン，七ンサフュージョン， マンマシンインタフェースの研究に従事。電子情 報通信学会, 情報処理学会, 精密工学会, 日本時計学会, IEEEの会 員.

(日本ロボット学会正会員)

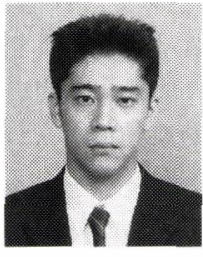

鈴木範史（Norihito Suzuki）

1972 年 1 月 17 日生. 1995 年中央大学理工学部精 密機械工学科卒業. 1997 年同大学大学院精密工学 専攻修士課程修了. 現在, NTT に所属. 